\title{
Disgruntled "Chronic Office Seeker" or Man of Political Integrity
}

\author{
James Baird Weaver \\ and the Republican Party in Iowa, \\ 1857-1877
}

\section{ThOMAS BURNELl COLBERT}

JAMES BAIRD WEAVER is remembered mostly as the presidential candidate of the Greenback party in 1880 and of the Populist party in 1892. Yet Weaver was not always a leader in agrarianbased third party movements. For almost twenty years he had distinguished himself as a Republican leader in Iowa. Consequently-especially during the years immediately after he left the Republican party-his detractors questioned the sincerity of his "radicalism," asking whether devotion to principle or a series of disheartening political defeats had dictated his departure from the Republican fold. Although a definitive answer to this question will never be developed, a review of Weaver's political life until he joined the Greenback party in 1877 coupled with some analysis of his character and attitudes can shed some light on his years as a Republican, the party infighting that affected him, and his decision to switch parties. From this examination it appears most likely that Weaver's sense of personal and political principle and integrity were the major motivations spurring him into the ranks of the Greenbackers.

Weaver was born in Ohio in 1833, but by 1848 his family resided in Bloomfield, in Davis County, Iowa. Abram Weaver, his father, was a strong Democrat; so too was James, who began practicing law in 1856. A talented speaker and debater, the younger Weaver had engaged in debates against antislavery Whigs as early as 1854 , arguing that to attack slavery would 
destroy the Union. Sometime in 1856, however, he began to change his mind. Influenced by Uncle Tom's Cabin and Horace Greeley's New York Tribune, he concluded that slavery was an immoral institution and took a leading part in abolitionist meetings. In 1857 he joined the Free Soil party, even though by his own account there were probably fewer than ten active Free Soilers in all of Davis County. Then when the Free Soilers merged with the Republican party, Weaver likewise formed a bond with Republicanism. In 1859 he campaigned vigorously for Samuel Kirkwood for governor; the next year he represented Davis County Republicans at the state convention and later voluntarily attended the Republican national convention in Chicago on his own funds in order to be a spectator at that gathering, which nominated Lincoln for president. ${ }^{1}$

When the Civil War began, Weaver volunteered for service. He entered the Union forces as an enlisted man; his company elected him first lieutenant; and he rose to the rank of colonel after seeing action in several battles. Eventually a brevetted brigadier general, Weaver was described in 1865 by a precise, yet subjective, observer as "one of the handsomest of the Iowa colonels. He has a symmetrical, well-developed person, which, with his dignified address, intelligent countenance, and dark-blue eyes, makes him interesting and pleasing. He is too small for a great man, and yet, with his dignity and self-assurance, he impresses a stranger favorably." He added, "intellectually, he is rather brilliant; I am told he is a graceful and interesting speaker."2

In all, Weaver's military record, combined with his personality and leadership attributes, gave him a position of prominence among Davis County Republicans, indeed throughout the state party organization. In 1865 he almost received the Republi-

1. Fred Emory Haynes, James Baird Weaver (Iowa City, 1919), 18-19, 23; "Annals Addenda," Annals of lowa 29 (January 1949), 557-58; Des Moines Register and Leader, 30 October 1911; James Baird Weaver, "Memoranda with Respect to the Life of James Baird Weaver," typescript in the James Baird Weaver Manuscripts, State Historical Society of Iowa, Des Moines; F. I. Herriot, "Iowa and the First Nomination of Abraham Lincoln," Annals of Iowa 8 (July 1907), $93,217$.

2. A. A. Stuart, Iowa Colonels and Regiments: Being a History of Iowa Regiments in the War of Rebellion (Des Moines, 1865), 75-76. For an account of Weaver's military record, see Haynes, Weaver, 25-58. 
can nomination for lieutenant governor, and in 1866 he was elected district attorney for the Second Judicial District. The next year President Andrew Johnson appointed him assessor for internal revenue for Iowa's First Collection District, a post he held until the office was abolished in $1873 .^{3}$

BY 1870 Weaver probably entertained hopes of eventually securing a seat in Congress from Iowa's First Congressional District. However, George W. McCrary had only gained the office in 1868, and the Iowa Republican party had an unwritten rule granting a first-term incumbent renomination. Thus at the district congressional convention in 1870, McCrary was renominated by acclamation, but at the same time Weaver was elected president of the convention. Furthermore, by some accounts, Weaver remained confident of ultimately replacing McCrary, who was his friend and who supposedly had promised to support Weaver for the congressional seat when his own tenure ended. ${ }^{4}$

Regardless of Weaver's congressional aspirations, some considered him a possible contender for the gubernatorial nomination in 1871 , but perhaps anticipating that McCrary would give up his congressional seat in 1872 , Weaver unequivocally declined to enter the race and endorsed C. C. Carpenter for governor. In early 1872 , however, Weaver's political plans suffered a setback. His Republican opponents in the First Congressional District, under the necessity of congressional reapportionment, made sure that Davis County was placed in the Sixth Congressional District. ${ }^{5}$

Nevertheless, Weaver attempted to receive the congressional nomination for the new Sixth District. The odds against him proved too great, however. All of the other counties in the Sixth District, except Davis, previously had been included in the old Fourth District. The only support for Weaver at the congres-

3. Haynes, Weaver, 68-69.

4. Iowa State Register, 1 June 1870, 11 May 1878; Fairfield Ledger, 2 June 1870. For a somewhat inaccurate account of Weaver and the 1870 convention, see David Brant, "Source Material of lowa History: David Brant's Political Sketches," Iowa Journal of History 53 (October 1955), 343.

5. Iowa State Register, 25 March 1871; Mildred Throne, Cyrus Clay Carpenter and Iowa Politics, 1854-1898 (Iowa City, 1974), 112; Brant, "Political Sketches," 343. 
sional convention came from Davis County delegates. The nomination went to William Loughridge, the two-term former congressman from the Fourth District. As for Weaver, he was chosen as presidential elector for the district. ${ }^{6}$

Two years later Weaver again sought the congressional nomination. This time his chances for success seemed excellent. Loughridge lacked support for renomination. Conflicts over patronage appointments had splintered party leaders in the district. Rank and file party members were also disgruntled. The Knoxville Iowa Voter, for example, a newspaper closely tied to former governor William Stone, not only opposed Loughridge for using "doubtful means" to secure his nomination in 1872 but also declared that the Republican party could hold the congressional seat only if Loughridge were not renominated. Loughridge, according to the Iowa Voter, was "a fair legislator but he has 'tricked' and betrayed the confidence of the leading Republicans in the Sixth District, hence he will meet with strong opposition and certain defeat if nominated." At about the same time, the Eddyville Advertiser announced that it would not support Loughridge even if he were renominated. The powerful Iowa State Register, the leading Republican organ in the state, concluded that a major problem for Loughridge was the lack of support for his candidacy from Republican editors in the Sixth District. ${ }^{7}$

On the other hand, Weaver appeared to be the strongest candidate in the district. The Davis County Republican described him as "A man of the people, he understands their wants and will always be true to their interests. His character is above reproach; he is in no way mixed up in the bitter personal fights in this district." In a similar vein, the Albia Union said of Weaver, "He is better known to most of our citizens by reputation, having earned a good name as a man of unswerving integrity, fine legal abilities, extensive general education, a clear head and logical oratorical powers." Although there were several other challeng-

6. Iowa State Register, 11 May 1878; Haynes, Weaver, 70; Edward Stiles, Recollections and Sketches of Notable Lawyers and Public Men of Early Iowa (Des Moines, 1916), 142.

7. Iowa Voter (Knoxville), 16, 30 April 1874; Eddyville Advertiser, cited in Newton Free Press, 29 April 1874; Iowa State Register, 17 July 1874. 
ers to Loughridge, most observers considered Weaver the contender with the "inside track" to the nomination. ${ }^{8}$

Republican leaders in the district soon concluded that none of the avowed candidates could stop Weaver, but that he might face tough competition from Judge Ezekial S. Sampson. The strongly anti-Loughridge Knoxville Journal (formerly the Iowa Voter) stated that Weaver was "daily developing strength" and if Sampson did not enter the race Weaver definitely had the lead. The paper then described Weaver as an able man "not wanting in reputation and integrity" with "a thorough knowledge of the needs and demands of the West and the entire country." But not all commentators agreed about Weaver's strength. The Sigourney News, for instance, believed that Sampson could be nominated and elected. Sampson, however, reportedly had informed Weaver that he would not accept the nomination "no matter where, how, or under what circumstances it might be tendered to him." Given Sampson's refusal to contend for the nomination, the Knoxville Journal thus predicted a week before the Republican Sixth District Convention that there was "little room for doubt" about Weaver's nomination, which he would secure on the second ballot by a large majority. ${ }^{9}$

When the Sixth District Congressional Convention convened on July 16,1874, Loughridge was not a candidate for renomination. On the informal ballot, Weaver led with 32 votes. John Morrison garnered 10 and Dr. C. C. Warden held 1 . Second to Weaver, though, was Sampson with 21. On the first formal ballot, Weaver still led, but he did not have enough votes to be nominated. On the second ballot, the delegates from Keokuk County, who had not been ready on the first ballot, now cast their votes. Then Morrison withdrew his name and cast the votes of his county delegation for Sampson, and one vote from Marion County previously for Morrison also went to Sampson. The final tally was Sampson 34, Weaver $33 .{ }^{10}$

8. Davis County Republican (Bloomfield), cited in Oskaloosa Weekly Herald, 14 May 1874; Albia Union, cited in ibid., 18 June 1874; Eddyville Advertiser, 4 July 1874.

9. Knoxville Journal, 18 June, 9 July 1874; Sigourney News, cited in Iowa Voter, 4 June 1874; Bloomfield Democrat, 6 August 1874; Oskaloosa Weekly Herald, 18 June, 2 July 1874 .

10. Knoxville Journal, 23 July 1874; Oskaloosa Weekly Herald, 23 July 
Weaver's supporters cried fraud. They argued that a delegate from Monroe County had decided to switch his vote from Sampson to Weaver, but Ben Elbert, chairman of the Monroe delegation, failed to announce the change. Even more upsetting was a report that prior to the balloting, Elbert had assured William J. Law and John A. T. Hull, Weaver's convention floor managers, that "the vote of Monroe county will be cast solid for Genl. Weaver." Relying on Elbert's profession of support, Law and Hull did not consult with the delegates from Monroe County. Then, after the nomination of Sampson was quickly followed by adjournment, apparently so that no one could challenge the balloting, Monroe County delegate H. R. Teller informed Weaver's friends that he had wanted to switch his vote from Sampson to Weaver, but Elbert refused to let him. Armed with this evidence of collusion, including an affidavit signed by Teller, Weaver's advocates sent a committee to Sampson, urging him to decline the nomination and endorse Weaver. Weaver's opponents also contacted Sampson, saying that he had to accept the nomination in order to ensure a Republican victory in the congressional contest. A few days later, Sampson announced his acceptance of the nomination. ${ }^{11}$

The whole affair received widespread newspaper coverage, and the story of Weaver's "slaughter" carried across the state. As in the old First District, Weaver had succeeded not only in distinguishing himself as a party leader but also in making enemies. Indeed, several considerations handicapped Weaver in 1874. For one, he had accepted an appointment from the detested Andrew Johnson. ${ }^{12}$ However, Johnson had long since left the White House, and Weaver had continued in that internal revenue office under President Grant. That point, then, was at best a minor concern for most.

More important was Weaver's support of the prohibition movement. A devout Methodist, Weaver unflinchingly embraced the cause of temperance. (He was remembered as one of

1874; Bloomfield Democrat, 23 July 1874; Iowa State Register, 17, 21 July 1874.

11. Davis County Republican, 23 July 1874; Iowa State Register, 17 July 1874; Des Moines Register and Leader, 30 October 1911; Eddyville Advertiser, 1 August 1874.

12. Haynes, Weaver, 70-73. 
the few soldiers during the war who never touched liquor. ${ }^{13}$ ) Politically, however, prohibition was an emotional issue that threatened to split the Republican party. The wise orthodox party man would have sidestepped the issue in 1874, but not Weaver. Against the advice of his friends, he had the temerity to address a temperance meeting just before the opening of the district convention. After the convention it was said that Weaver's Methodism and views on prohibition caused his defeat. And almost forty years later Weaver himself recalled that the motion for adjournment at the convention was met with cries of "we have defeated the $\mathrm{d}----\mathrm{d}$ prohibitionist."14

Behind the commotion about Weaver's temperance stand, however, there were factional issues that also fostered his defeat. At least one critic at the time concluded that Weaver had been victimized by the "Old District Ring." His opponents for the nomination had joined together to defeat his bid for the congressional seat not so much over the prohibition issue but for more personal reasons: Weaver would not agree to keep the present holders of federal appointments in the district in those positions. ${ }^{15}$

Further contributing to Weaver's defeat, yet even more below the surface, was Weaver's alignment with former senator James Harlan and his wing of the state Republican party. Harlan, also a staunch Methodist and prohibitionist, had been one of the early leaders of the Republican party in Iowa. However, in 1872 he had lost his seat in the United States Senate to William Boyd Allison. The two were in the midst of a power struggle in 1874, but Allison, in league with Grenville Dodge and other powerful Republicans, had a decided edge over Harlan and his friends. Undoubtedly Weaver's defeat could be connected in part to his allegiance to Harlan. ${ }^{16}$

13. Stuart, Iowa Colonels, 76 .

14. Bloomfield Democrat, 3 September 1874; Des Moines Register and Leader, 30 October 1911.

15. Bloomfield Democrat, 23 July, 6, 13 August 1874.

16. Ibid., 7 October 1875; Haynes, Weaver, 73. For an analysis of the Harlan-Allison struggle, see Leland L. Sage, "Weaver in Allison's Way," Annals of lowa 31 (January 1953), 485-507; also see Sage, William Boyd Allison: A Study in Practical Politics (lowa City, 1956), 91-142. 
No DOUBT FRUSTRATED by his political fortunes in 1874 , Weaver nonetheless remained undaunted in his office-seeking efforts. Iowans were to elect a new governor in 1875, and at the urging of the temperance element of the Republican party, and probably Harlan, Weaver sought that nomination. He conducted an unprecedented campaign, traversing the state soliciting voter support. Consequently, a majority of the delegates to the state convention in 1875 were committed to Weaver. But when the call for nominations came, Dr. S. M. Ballard of Audubon County stirred the delegates by nominating former governor Samuel Kirkwood. This nomination generated surprise, for it was well known that Kirkwood desired the U.S. Senate seat held by George Wright, who had announced that he would retire in 1876, and Kirkwood, considering it improper to seek the governorship when he had no intention of staying for a full term, had forcefully stated his refusal to accept the gubernatorial nomination. Regardless of Kirkwood's expressed wishes, however, a dramatic convention show ensued in which Allison's Dubuque County delegation helped "stampede" the delegates toward Kirkwood. ${ }^{17}$

A delegate from Dubuque, General M. M. Trumbull, marched over to Ballard and demanded by what authority he offered Kirkwood's name. "By the authority of the great Republican Party of the State of Iowa!" Ballard replied. With that response, considerable cheering erupted. At that point, two of the other nominees, John Russell and John Gear, each withdrew their names in favor of Kirkwood. Weaver, on the other hand, let his name stand. On the informal ballot he trailed Kirkwood by 68 votes. The formal ballot was quickly held, but before it could be counted, Weaver's campaign manager moved that Kirkwood's nomination be made unanimous. Kirkwood's acceptance, however, had to be prodded from him. Finally, after a deluge of telegrams and a delegation from the convention arrived at his home, he wired a friend at the convention, "If I must, say yes for me. ${ }^{118}$ 490-92.

17. Brant, "Political Sketches," 341; Sage, "Weaver in Allison's Way,"

18. Brant, "Political Sketches," 343-45; J. A. Swisher, "A Convention 
Weaver had lost again, but he was not done fighting. At the evening session of the convention he fought to place a prohibition plank in the state platform, but after much debate the session ended without the endorsement of any statement on prohibition. ${ }^{19}$ Late that same evening Weaver addressed the Temperance party convention, which was also being held in Des Moines because party leaders had hoped to prompt the Republicans into taking a stronger stand on the liquor question. Tired and dismayed after his defeat at the Republican convention, Weaver nonetheless admonished the temperance crowd against creating a separate political party. He told the gathering that he would "allow no one to exceed" him "in endorsing temperance principles," but he could not "favor the organization of a third party" because the "temperance cause would thereby lose more than it would gain." Weaver advised that they look to the Republican party to achieve their ends. ${ }^{20}$

Again Weaver's temperance stand had loomed large in the foreground of his candidacy while party factionalism had done much to dictate his defeat. This time the two concerns intertwined. Many feared that if Weaver received the Republican nomination for governor, his support for prohibition would cost the party many votes. Not only might he lose the governorship but, closer to home for many, his candidacy could hurt the party in local elections. And if Republicans failed to keep control of the state legislature, they would lose the U.S. Senate seat. For Allison and his crew, the concern was twofold. They both feared losing control of the legislature and cringed at the prospect of Weaver in the governor's chair when the legislature would elect a new senator. Weaver might use the power of the office to help Harlan return to the Senate. Thus it was to the mutual satisfac-

Stampeded, " Palimpsest 9 (1928), 353; Sage, "Weaver in Allison's Way," 49394; Cyrenus Cole, Iowa Through the Years (Iowa City, 1940), 344-45. Brant, 344 , recalled that Kirkwood sent telegrams to his fellow Johnson County Republicans at the convention expressing his "declination" of the nomination, which caused even more concern, for it was purported that Weaver had decided not to accept the nomination if it were offered to him as a result of Kirkwood's refusal.

19. Iowa State Register, 25 June, 1 July 1875; Haynes, Weaver, 80-81; Brant, "Political Sketches," 345-46.

20. Iowa State Register, 1 July 1875. 
tion of the anti-prohibitionist and anti-Harlan Republicans that Kirkwood received the nomination, not Weaver. ${ }^{21}$

After Weaver returned to Bloomfield, it was generally assumed that he would be nominated for the state senate. ${ }^{22}$ Weaver, however, must have been seriously reassessing his political prospects in Iowa, for in mid-July he wrote to Senator Wright, asking if "in the near future" Wright would have the opportunity to present Weaver's name "for a foreign appointment that would be worth accepting. ${ }^{23}$ Whether or not Wright sought a foreign post for Weaver soon became inconsequential, for Weaver jumped back into the political fray: Davis County Republicans nominated him by acclamation for the state senate. And when accepting the nomination, Weaver uncompromisingly declared, "There is one thing, however, which I wish clearly understood, one thing I intend to live and die by-I am a prohibitionist." 24

Unfortunately for Weaver, he faced a tough battle, despite his political prominence. The Democratic party in Davis County was one of the strongest in the state, and he faced a popular incumbent. Worse yet, his efforts suffered a blow from Kirkwood. Throughout the campaign, Weaver gave many speeches in support of Kirkwood, but when Kirkwood delivered a major address before several thousand in Bloomfield, he rejected prohibition. Whether Kirkwood was merely being honest-he was not a practitioner of temperance-or stating his position as he had throughout the state, or hoping to capitalize on local antipathy

21. Kirkwood to Clarkson, 6 November 1875 , James S. Clarkson Manuscripts, Library of Congress, Washington, D.C.; Bloomfield Democrat, 7 October 1875; John Mahin to Weaver, 31 October 1911, Weaver Manuscripts; Brant, "Political Sketches," 343; Sage, "Weaver in Allison's Way," 490. Haynes, Weaver, 76-77, does not go into the Allison-Harlan backdrop to actions at the convention, maintaining that Weaver was defeated by the "anti-prohibition and pro-corporation delegates." James S. Clarkson, "The Stampede from General Weaver in the Republican Convention of 1875," Annals of Iowa 10 (January 1913), 564-66, influenced Haynes's interpretation of the causes of Weaver's loss. It is surprising, though, that Clarkson does not mention the AllisonHarlan conflict, for as editor of the Iowa State Register he had been an important insider in the Allison forces. For a full survey of the convention, see Iowa State Register, 30 June, 1, 2 July 1875.

22. Bloomfield Democrat, 15 July 1875 .

23. Weaver to Wright, 18 July 1875, Weaver Manuscripts.

24. Bloomfield Democrat, 2 September 1875. 
to prohibition, or endeavoring to hurt Weaver's campaign, the result was that he helped spell yet another defeat for Weaver, who lost the election by 139 votes. Weaver, in turn, considered Kirkwood's action devastating to his campaign and concluded that Kirkwood, who greatly desired the U.S. Senate seat, did not want Weaver, who supported Harlan for the office, in the state senate. $^{25}$

During his ill-fated campaign for the state senate, Weaver had not only touched on the temperance issue, but he had also given attention to two other controversial concerns: the power of railroad corporations and the money question. He accused his Democratic opponent of being "bought" by railroad interests. The previous year the state assembly had enacted the so-called Granger Law for controlling railroad shipping rates, a popular piece of legislation drafted by Frank T. Campbell, who had managed Weaver's fight for the gubernatorial nomination. Thus Weaver strove to position himself squarely on the side of the reformers in praising the law, supporting the principle of rate regulation, opposing the power of railway corporations, and championing the interests of farmers and merchants. ${ }^{26}$ On the matter of monetary policy, he uncharacteristically skirted the issue, contending that, according to decisions of the Supreme Court, the paper money in circulation was legal tender, acceptable for the payment of debts, but it could only be issued in wartime emergency. ${ }^{27}$ By the spring of the next year, however, Weaver was giving much more attention to prevailing economic problems and their spawn, inflationary views calling for the infusion of more paper currency into the money supply.

25. Bloomfield Democrat, 16 September, 14 October 1875; Davis County Republican, 9 September 1875; Brant, “Political Sketches, 341; Des Moines Register and Leader, 30 October 1911; Dan Elbert Clark, Samuel Jordan Kirkwood (Iowa City, 1917), 337.

26. Haynes, Weaver, 84-85; Bloomfield Democrat, 7 October 1875; Leland L. Sage, A History of lowa (Ames, 1974), 191. Timothy Walker, editor of the Bloomfield Democrat, charged (23 September 1875) that Weaver conducted a "pig and pup" campaign by speaking for temperance to Methodist voters and against railroads to others.

27. Haynes, Weaver, 84; Bloomfield Democrat, 23 September 1875; Iowa State Register, 20 September 1878 . What Weaver probably referred to were the Legal Tender Cases of 1871, in which the U.S. Supreme Court reversed an earlier decision and declared that greenbacks were legal tender. 
The CONTROVERY OVER GREENBaCKS had first flared at the end of the Civil War. During the war Congress had authorized the Treasury Department to issue 450 million dollars worth of paper currency, commonly called greenbacks. The value of this money depended solely on the national government's credit and its promise to redeem it in specie at a later date. With the war's conclusion, the Treasury Department hastened to withdraw greenbacks from circulation because they had contributed to a severe inflation. Opponents of this policy, on the other hand, feared a depression due to a depletion of the money supply. In 1868 Congress forbade further contraction of greenbacks, and a movement began to seek an increase in the number of available greenbacks. After support of socalled "soft money" became part of the Democratic platform in 1868, many interpreted the Democratic defeats that year as a repudiation of greenbackism, although the movement retained adherents in both major parties. When the nation slipped into depression in 1873, the inflationists revived their demands. Their efforts, however, suffered a major setback in 1874 when President Grant vetoed the "Inflation Bill," which would have put more greenbacks in circulation. The next year, their hopes were dashed even more when hard money proponents in Congress engineered the passage of the Resumption Act, which provided for replacing greenbacks with gold coins. ${ }^{28}$

With the major parties failing to adopt soft money ideas, greenback supporters created new political alignments throughout the nation, including the West, where the number of greenback advocates increased as farmers struggled with economic problems. On the whole, farmers had enjoyed good crop yields and good prices during the war years, and with the promise of continued prosperity, many expanded their operations by purchasing additional land and new implements, financed through mortgages on other real estate and chattel. However, the depression of 1873 brought low prices for agricultural produce, and farmers' ability to

28. For more on the origin of greenbacks and the controversy surrounding them, see Robert P. Sharkey, Money, Class, and Party: An Economic Study of Civil War and Reconstruction (Baltimore, 1959); Irwin Unger, The Greenback Era: A Social and Political History of American Finance, 1865-1879 (Princeton, 1964); Horace Samuel Merrill, Bourbon Democracy of the Middle West, 1865-1896 (Seattle, 1953); and Chester McArthur Destler, American Radicalism, 1865-1901 (Chicago, 1946). 
pay off their debts was compromised. Some lost their property, while others took out second mortgages. On top of such burdens, the Resumption Act seemed particularly baneful. Loans received in greenbacks would have to be repaid with interest in more valuable gold dollars after 1879. In response to their plight, many began to reason that if more greenbacks were issued and the Resumption Act repealed, debts incurred in greenbacks could be paid off in kind and prices on farm products would rise. To realize such a possibility, some distraught Iowa farmers, along with others upset with national monetary policy, left their old political parties and turned to organizing a new party. ${ }^{29}$

Inflationists in Iowa, soon to be called Greenbackers, held a convention on May 10,1876; and like many others of their ilk across the nation, they created a new political party, the Independent party of Iowa. The delegates adopted a platform expressing prevalent inflationist demands: repeal of the Resumption Act, withdrawal of national bank notes, and issuance of a uniform national currency. They also selected delegates to represent Iowa at the forthcoming national meeting in Indianapolis. One of those chosen was Weaver. ${ }^{30}$

A week later Weaver was among the 230 delegates from eighteen states who took part in the proceedings at Indianapolis. There they adopted a platform and nominated presidential and vice-presidential candidates. Then at the last minute they added to their platform a demand that silver be remonetized, for the renewed coining of silver could also increase the amount of currency in circulation. ${ }^{31}$

29. Everett E. Edwards, "American Agriculture-The First 300 Years," in Farmers in a Changing World (Washington, D.C., 1940), 261; U.S., Congress, House Miscellaneous, Causes of General Depression in Labor and Business, 46 th Cong., 2d sess., 1879-1880, vol. 1; Clyde Orval Ruggles, "The Economic Origins of the Greenback Movement in Iowa and Wisconsin, ${ }^{\prime}$ Proceedings of the Mississippi Valley Historical Association for the Year 1912-1913, 6: 142-165.

30. Iowa State Register, 11 May 1876; Clyde Orval Ruggles, "The Greenback Movement in Iowa" (M.A. thesis, University of lowa, 1907), chap. 2, pt. 1; Herbert S. Fairall, Manual of lowa Politics, State and National, Conventions, Platforms, Candidates, and Official Vote of All Parties from 1838 to 1884 (lowa City, $1884), 100-101$. For the history of the Greenback party in Iowa, see Fred Emory Haynes, Third Party Movements Since the Civil War with Special Reference to Iowa (Iowa City, 1916), 153-201.

31. Unger, Greenback Era, 305-7; Ruggles, "Greenback Movement in Iowa," chap. 2 , pt. 2. 
Regardless of his increasing interest in the economic crisis and the Independent party, Weaver did not desert the Republican party. He did, however, contemplate challenging Sampson for his congressional seat, saying that he conceded the incumbent's right to run again if "in opposition to the repeal of the Resumption Act, and his opposition to making silver a legal tender for all sums, he expresses the will of the Republican voters of the Sixth District." Although some of his Republican friends championed replacing Sampson with Weaver, nothing came of their efforts, and Sampson received renomination without opposition. ${ }^{32}$

While Republicans in the Sixth District generally accepted the hard money position of the Republican party, obviously the Independents did not, and when they met in convention in August, Weaver received the most votes in the informal ballot for their congressional nomination. One of Weaver's supporters immediately telegraphed him, requesting that he accept the nomination. But Weaver responded, "No, I am for Hayes and Wheeler, Silver and Greenbacks." And during the ensuing campaign he worked vigorously for Republican candidates. ${ }^{33}$

When the Republicans of Iowa prepared for their state convention in the spring of 1877 , the issues most dear to Weaverprohibition and currency reform-were ones that no longer could be shunted aside. Again a delegate, Weaver endeavored to gain a place on the resolutions committee, but he failed. Instead, he received the honorary position of a vice-president of the convention. ${ }^{34}$

Nevertheless, he should have been heartened by the actions of the convention. His former close supporter and fellow prohibitionist, Frank Campbell, received the nomination for lieutenant governor, and the resolutions committee presented a platform that endorsed the remonetization of silver and advocated the maintenance of the prevailing volume of currency. Weaver and the other temperance men were even able to gain 1876.

32. Iowa State Register, 11 May, 19 July 1876; New Sharon Star, 24 July

33. Iowa State Register, 2, 3 September 1876; Oskaloosa Herald, 26 September 1876; New Sharon Star, 24 July 1876; Haynes, Weaver, 61, 91.

34. Iowa State Register, 29 June 1877, 11 May 1878. 
the adoption of a resolution calling for the "rigid enforcement" of existing prohibition laws. ${ }^{35}$

The only result of the convention that distressed Weaver was the nomination of John Gear for governor. Little love was lost between the two. Gear had been involved in the reapportionment manipulation that had moved Davis County out of the First District; his actions at the state convention in 1875 had contributed to Kirkwood's nomination; he had the backing of railroad interests; and more immediately important, Gear was no friend of prohibition. ${ }^{36}$

But because Gear was the party's nominee and since the party had taken a stand on prohibition laws, Weaver felt compelled to mollify the hard feelings that continued between Gear and ardent temperance people. Weaver published a letter directed to temperance advocates, stating that with the Republican party of Iowa "openly and squarely committed ... to the cause of prohibition," he was "entirely satisfied." Despite his earlier opposition to Gear, Weaver would "now support him very unreservedly, and would have faith that he would not undermine the expressed will of the party. ${ }^{\prime 37}$

A few weeks later, though, Weaver surprised the Iowa political world by leaving the Republican party. In a letter to Gear requesting that the gubernatorial candidate release him from a pledge of support, Weaver cited his difference "with the Republican party upon the question of finance," declaring that he could no longer "remain silent" about a "gigantic wrong." He now cast his lot with the Independents" with great rejoice." ${ }^{38}$

Weaver went on to become a state then national leader for the Greenback party in the 1880 s, and in the 1890 s he helped to

35. Ibid.; Fairall, Manual of Iowa Politics, 103-4.

36. Haynes, Weaver, 88; Burlington Hawkeye, 1 July 1875; Brant, "Political Sketches," 346-48; Sage, "Weaver in Allison's Way," 503; William Fleming to Cyrus C. Carptenter, 15 June 1877, Carpenter Manuscripts, State Historical Society of Iowa, Iowa City.

37. Iowa State Register, 12, 13 July 1877.

38. Weaver to Gear, 29 August 1877, Weaver Manuscripts. Gear replied, "I release you from your promise but regret-not on personal grounds-that you see it your duty to leave the Republican party in which you have done such loyal service to train in our camps." Gear to Weaver, 31 August 1877, Weaver Manuscripts. The Greenback party supported prohibition, so Weaver in no way modified his stand on that sensitive issue when he joined the Greenbackers. 
develop the Populist party. He never again entered the ranks of the Republicans, but he did at times cooperate with the Democrats. Fostering fusion movements, he gained election to Congress three times, and in 1896 he helped Democratic presidential standard bearer William Jennings Bryan gain the Populist nomination.

WEAVER'S WHOLE POLITICALCAREER shows a man of ability and dynamism. Nonetheless, the question of his true devotion, or lack thereof, to political parties or their principles partially colored his reputation. Throughout his political life he did find himself operating in several parties. His opponents even came to dub him "Jumping Jim." And despite his profession of devotion to Greenbackism and Populism, he was not above cooperating with Democrats in order to secure election to office-a tactic that angered several of his uncompromising fellow party members and provided a basis for criticism from his detractors in the two major parties. ${ }^{39}$ Yet the evident consistencies in his character and attitudes shed some light on his politics, including his decision to foresake the Republican party.

No one can doubt that Weaver harbored lofty aspirations. He wanted high office, and in some respects that was a detriment to him. Older, established Republican leaders saw Weaver as a "dangerous man ... popular and ambitious ... a dashing young man who spoke with a silver tongue." According to Edward Stiles, one of Weaver's contemporaries who wrote about Weaver and many other notable Iowans of the times, some thought "that the General's ambition was too vaulting and that he was too active in enforcing his aspirations." A modern historian who has done much research on political life in Iowa during Weaver's era has opined that Weaver did not engender so much disfavor from Republican regulars merely because of his prohibitionist views but because on that and other political issues he was seen as "inclined to be an extremist, an emotional idealist rather than a political realist." ${ }^{40}$ Then, too, Weaver's connection

39. For a good example of such criticism and the rancor associated with it, see Ralph R. Ricker, "The Greenback-Labor Movement in Pennsylvania" (Ph.D. diss., Pennsylvania State University, 1955), 124-27.

40. Cole, Iowa Through the Years, 344; Stiles, Recollections and Sketches, 146; Sage, History of Iowa, 196. 
with James Harlan worked against him. But did these considerations drive him from the Republican party? Did he desert the party in bitterness over defeats or over principle?

In 1877 Weaver's former Republican brethren proclaimed that he had become a sore loser. They refused to believe that his conversion to Greenbackism had any basis in principle, preferring to regard him as a "soured" politician, a "chronic office seeker" who had sacrificed his political scruples in order to capitalize on the developing appeal of the Greenback party. The editor of the Sioux City Journal even concluded that Weaver had a wild idea of getting elected to the U.S. Senate by switching parties. ${ }^{41}$

On the other hand, James S. Clarkson, a leading member of the Allison clique and the editor of the Iowa State Register who denounced Weaver in 1877 for bolting from the Republican party, declared many years later that Weaver had been driven to leave the party "in vindication of his self-respect." Clarkson further stated, "It is to be said now, to the eternal credit of General Weaver, that the main motives and desires of his life always were to serve his fellow man." ${ }^{2}$ Clarkson's appraisal was probably closer to the truth than those of Weaver's skeptical critics.

If purely personal gain had motivated Weaver's political decisions, he probably would have acted differently over the years. For instance, if self-gain had dictated his actions, he would not have remained loyal to James Harlan for so many years. ${ }^{43}$ Perhaps even more significant was Weaver's response to a purported offer in 1883, when Harlan, representing the Republican leadership in the state, offered Weaver the congressional seat of recently deceased M. E. Cutts, who had defeated Weaver in the previous election. According to Weaver, Harlan implied that if Weaver would become a Republican again he would eventually be elected to the U.S. Senate. ${ }^{44}$ But Weaver

41. Haynes, Weaver, 87-88; Iowa State Register, 27 September 1877, 11 May 1878.

42. Clarkson, "Stampede," 567-68.

43. In January 1876 Weaver served as one of Harlan's chief campaign managers in an effort to have Harlan elected to the U.S. Senate again - at a time when Harlan realistically did not have enough strength to defeat Kirkwood, the choice of the Allison-Dodge faction. Sage, "Weaver in Allison's Way," 504-7; Haynes, Weaver, 88.

44. Des Moines Register and Leader, 30 October 1911; Clarkson, "Stampede," 567. For Weaver's later career, see Haynes, Weaver, 101-443. 
rejected the overture, for he was not a political chameleon who sought office only for self-advancement. Regardless of the force of his ambition, it was part of his character to adhere to policies that he believed to be correct and to work with others who also advocated those policies.

In 1877 Weaver no longer perceived the Republican party as still the party of Lincoln representing the interests of common folk. In particular, the position of the national Republican leadership on the money question prompted his decision to join the Greenback party. As he said at the time, reading a recent speech by Treasury Secretary John Sherman convinced him that the Republican party would not rescind its policies of specie resumption and currency contraction no matter what appeals for a softening of those positions might emanate from party faithful. Sherman's remarks were for Weaver "the straw that broke the camel's back." ${ }^{\prime 45}$ In 1878, while campaigning for a congressional seat as a Greenbacker, Weaver further explained his view of the Republican party and his departure from it.

What do you think of a party so far in the clutches of the money sharks and shylocks that the people wish to add to their currency, and not only the people, but Congress itself, but are unable to do it? Facts like these . . . opened my eyes. I saw . . . a reform was necessary; that is the reason I came out of the Republican party. . . . You don't have to kill anybody when you form a new party. You don't have to move out of the neighborhood. You take the same men and organize them anew. ${ }^{46}$

Throughout the rest of his political career, Weaver defended his decision to leave the Republican party on the grounds that after an "investigation" of its "principles" he concluded "that its policy was hostile to the interest of the people, and that there was no possible chance of reforming that party. ${ }^{n 7}$ During his early years as a Greenbacker he often became frustrated as his antagonists attacked him for being a "traitor" to the Republican party rather than debate issues. From the first, though, he did

45. Iowa State Register, 20 September 1877.

46. "Address of Gen. J. B. Weaver, Delivered at Newton, Iowa, on the Afternoon of Saturday, June 29, 1878," printed copy in Weaver Manuscripts.

47. Congressional Record, 46th Cong., 3d sess., 1880, 11:310. 
not avoid a confrontation over the matter. Rather, he used it to his own advantage. During a debate with Ezekial Sampson in 1878 , for example, he charged,

the Republican party has surrendered the government's most important function of issuing and controlling our money to the banks; your answer, "Weaver has switched his politics"; I plead guilty. Now will you answer? I charge the Republican party violates the Constitution, which provides that Congress shall control commerce between states, by permitting railroads to fix their own freight rates between all the states from Maine to California; you answer, "Weaver is an of fice seeker." I am; I seek the of fice you now hold. Now will you defend or denounce your party's action? ${ }^{48}$

Thus, for the most part, the judicious historian can agree with Weaver's biographer, Fred Emory Haynes, who concluded that Weaver left the Republican party after "His own political experience had brought home to him the fact that the Republican party had ceased to be one of high ideals, whose interests were primarily for the people." 49 But Haynes did not go far enough in developing his understanding of Weaver's motivations, for Weaver's politics were also connected with his social and religious morality. His strongly held Christian convictions played an important role in influencing his political views as well as providing justification for them.

A religious man firmly moored to the Methodist church, Weaver was remembered, for example, as the longtime superintendent of the Methodist Sunday School in Bloomfield who "seemed absolutely happy when he led the children in singing." Perhaps, though, the depth of his faith was best exhibited during the Civil War. His letters to his wife were filled with lines such as "do not forget to be religious"; "I would rather serve God and make you happy than anything that could be thought of on this earth"; "Will you earnestly and continually join me in worshipping the good and the Great Lord?" Moreover, he did not limit his religious expression to personal correspondence, for at roll call after the Battle of Fort Donelson, Weaver, according to

48. Harry C. Evans, The Pioneers and Politics of Davis County, lowa (Bloomfield, Iowa, 1919), 41-42.

49. Haynes, Weaver, 94. 
one of his comrades, "stepped out and said he had asked God to forgive him for his blasphemy [swearing] when they were shooting our boys down, and he wanted us to forgive him, too." ${ }^{\text {. }} 0$

Weaver, then, was a man filled with strong spiritual commitment and energy, which found expression in his politics. Religious references appear throughout his speeches. Although his utterances might be considered merely rhetorical devices employed by a gifted orator, Weaver clearly did not use such language flippantly. Rather, he approached politics as something of a "crusader," fired with zeal for advancing righteous causes in which political and religious principles merged. "Don't have one principle for the prayer meeting, and another for the ballot box," he told a crowd of listeners in 1878. "Take the honest laboring classes, take that for your cause, and you will be on the Lord's side. Don't pray to get the Lord on your side, but just get on his side, for he is a friend to the poor and oppressed." In a similar vein, in his first speech as a congressman in 1879, he declared that the two major parties had not brought the nation necessary relief; a "new organization must do it, and the Lord is raising up that party [Greenback] now." His message did not change over the years. Writing in 1892, he said of Populism, "Such is the character-such is the interpretation of the mighty movement. ... It is the religion of the Master in motion among men.... thanks to the all-conquering strength of Christian enlightenment we are at the dawn of the golden age of popular power. ${ }^{n 1}$ Clearly, Weaver considered working for the interests of the common folk - the people-against the wealthy and powerful vested interests, especially banks and corporations, as being engaged in a Christian effort.

Throughout his political career, James Baird Weaver consistently placed his understanding of "right action" before "expediency." At the same time, he did have obvious personal reasons for leaving the Republican party, and in 1876 he may have merited description as a sulking, defeated political warrior who "lingered for a while in an Achilles tent" until "a new idea

50. Davis County Republican, 12 December 1933; James Baird Weaver to Clara Vinson Weaver, 22 August, 3 September 1861, 12 October 1862, Weaver Manuscripts; E. A. Allen, The Life and Public Services of James Baird Weaver (Cincinnati, 1892), 26.

51. "Address of Gen. J. B. Weaver ... June 29, 1878"; Haynes, Weaver, 112; James Baird Weaver, A Call to Action (Des Moines, 1892), 440, 442. 
[Greenbackism] ... tempted the man in the tent, and revived his fighting spirit." ${ }^{2}$ He returned to the political "battlefield," however, to advance what he considered a just, indeed moral, cause, not just his own political fortunes. Thus Weaver, who had entered the Republican party when it was young and the voice of reform, left it two decades later for a new camp of reformers, the Greenback party, where his strong conviction in the correctness of his action combined with his political abilities quickly propelled him into prominence as a spokesman for agrarian radicalism.

52. Cyrenus Cole, I Remember I Remember: A Book of Recollections (lowa City, 1936), 99. 
Copyright of Annals of Iowa is the property of State of Iowa, by \& through the State Historical Society of Iowa and its content may not be copied or emailed to multiple sites or posted to a listserv without the copyright holder's express written permission. However, users may print, download, or email articles for individual use. 